\title{
CURRENT STRATEGIES OF URBAN AND ARCHITECTURAL CONVERSION AS A RESULT OF INCREASED HOUSING DEMANDS
}

\author{
Milica Živković, Nađa Kurtović-Folić, Goran Jovanović, Slaviša Kondić, Mihailo Mitković
}

Preliminary notes

In the contemporary world of social and demographic changes that continuously transform and intensify the housing demands, the exploitation of existing building fund for the development of new residential environment could be a sustainable solution to the problem of overcrowding in the cities. Conversion of obsolete buildings that are out of their primary functions to residential facilities is one of the current methods of highly-urbanized areas revitalization. Since the conversion is only one of the possible methods of urban renewal, because more radical measures of building demolition and land conversion are very often applied, it is necessary to analyse the quality and suitability of this approach. The paper points out the advantages of building conversion implementation in the field of housing and explores the general characteristics of the current local and international strategies of conversion and urban regeneration.

Keywords: conversion; housing; obsolescence; sustainability

Postojeće strategije urbane i arhitektonske konverzije kao rezultat povećane potražnje za stambenim prostorom

Prethodno priopćenje

U postojećem svijetu društvenih i demografskih promjena koje neprestano mijenjaju i povećavaju potražnju za smještajem, iskorištavanje postojećeg građevinskog fonda za razvoj novih stambenih prostora mogao bi postati održivo rješenje problema prenapućenosti gradova. Konverzija zastarjelih zgrada, koje su izgubile svoju primarnu funkciju, u stambene objekte, jedna je od postojećih metoda za revitalizaciju visoko-urbaniziranih područja. Budući da je konverzija samo jedna od mogućih metoda urbane obnove, jer se vrlo često primijenjuju radikalnije mjere demoliranja zgrada i konverzije zemljišta, potrebno je analizirati i kvalitetu i prikladnost ovoga pristupa. U radu se naglašavaju prednosti implementiranja konverzije zgrada kad se radi o smještaju te se istražuju opće karakteristike postojećih lokalnih i internacionalnih strategija konverzije i urbane regeneracije.

Ključne riječi: konverzija; smještaj; zastarijevanje; održivost

\section{Introduction}

In the existing urban areas, there are more and more abandoned buildings that face the problems of economic, technological, social or functional obsolescence, which may be conditioned by the building characteristics or resulted from the aspects of the wider environment. On the other hand, during the progressive growth of the world population, the need for new residential environment in already defined and densely populated urban structures has become an imperative of planning policy at the global level.

Conversion, as an approach of sustainable development, is a possible solution to the problem of obsolescence and abandonment of architectural heritage and growing demand for new housing environment. It can be defined as the revitalization process of the buildings that are out of their primary functions in order to accept new and different functions, appropriate to their historical value [1]. The building function value strengthens social relations and enhances the connection between people and historic environment [2]. Thereat, it is not enough to put the building in function again, but also to achieve the energy efficiency and provide a healthy environment through its reuse. Therefore, it is necessary to identify the architectural heritage as a renewable resource rather than a product to be exploited or rejected [3].

Conversion of historic buildings is one of the key initiatives in numerous countries around the world, and the leading ones are Canada, Australia, China and the United States. It also includes a number of conversion projects of prestigious organizations such as the DEHDepartment for Environment and Heritage, the NSW
Department of Planning, the RAIA International-Royal Institute of Architects, UNESCO, etc.

Since the conversion is only one of the possible methods of urban renewal, because in practice more radical measures, such as demolition of existing buildings and construction of new facilities, are very often applied, it is necessary to analyse the quality and suitability of this approach. Decisions regarding the implementation of conversion in order to build a new housing environment should be based on the possibilities and limitations that are unique to each individual building.

Assessment of the suitability of its implementation requires the identification of measures that must be conducted in order to achieve a balance between the user needs and the established principles of sustainable development. The objectives of the study are:

- evaluation of suitability and feasibility of conversion as an approach to solving the exposed problems,

- identification of the buildings that are suitable for this kind of transformation on the basis of pre-defined evaluation criteria,

- identification of intervention types that are most commonly used in local and international practice as well as definition of the spatial frameworks within which they are implemented.

\section{Sustainable conversion of building heritage}

The possibility for sustainable cities formation, through the use of existing facilities that are out of their function, can be understood through coordination of a multitude of measures at the local and national level, coupled with the initiative of further development, energy efficiency and protection of existing resources [4]. 
Building conversion as a method of sustainable development primarily provides:

- protection of historical and architectural integrity of the building,

- revitalization of urban areas through the adoption of new functions,

- minimization of the negative impact on the environment,

material, human and energy resources savings.

The principle of building conversion, therefore, can be defined as the potential for further use and exploitation of functionally obsolete buildings, which could also be called "recycling" of facilities [5]. Recycled architectural elements make their contribution to the fulfilment of modern model of integrated conservation, inevitable in the context of sustainable urban development. In energy conservation terms, historic areas, buildings and spaces represent an embodied energy which has long since discharged environmental impacts, so that the positive reuse and enhancement of historic buildings and spaces is one of the most sustainable actions that can be taken [6]. The balance between the strategy of building heritage preservation, through development of a structure sustainable in the present, and tendency of sustainable development in the future, is one of the main goals of the modern world.

\section{Obsolete building conversion to residential uses}

In the contemporary world, characterized by a sudden increase of world population, the existing housing stock does not provide sufficient capacity to accommodate the population in already defined urban patterns. Due to the growing need for compact residential areas with higher density, multi-family housing is imposed as a necessity in contemporary residential architecture. The conversion of obsolete buildings for the purposes of multi-family housing is the result of a growing need for upgrading the existing housing fund and preserving the architectural heritage and the living environment.

This type of conversion has potential economic, environmental and social benefits [7]. Exploitation of the buildings that are out of any function for the housing development, provides the protection of valuable resources of social community, reduces construction and land acquisition costs and housing rent. Saving additional energy and material resources through adaptive reuse significantly reduces the cost of square meters of residential space in comparison to the space in the new building. This implies the resources savings in all phases of building construction, from the exploitation of natural resources to product delivery, including the production of materials, equipment, transportation, administrative tasks and so on. The building conversion process creates a healthy housing environment and prevents further air pollution by the harmful products of construction. Seen from the social point of view, the qualities of conversion are reflected in a better connection of surroundings with the existing built environment that offers residents and immediate neighbourhood a sense of belonging. In this regard, sustainable development should have as an aim the development of the cities that are useful and rich in resources, not only in terms of their form and energy efficiency but also in terms of their function as a place to live.

The current movement of sustainability advocates the development of compact and revitalized urban areas where, due to overloading of transport networks, the demand for housing located near jobs is increasing. With the development of modern tenant structures, such as young couples, students and people with an alternative lifestyle that prefer frequent and dynamic urban areas, the radical changes in the system of town planning were made. Among others, they included relocation of the residential areas in the central parts of the city. Upgrading of residential environment in urban centres encourages revitalization, improves the stability and vitality of the urban core and overcomes already well-established phenomenon of housing relocation to suburban areas.

\section{The method of evaluating the suitability of conversion}

In order to implement a qualitative evaluation of building suitability for acceptance of housing functions, it is necessary to define the general housing requirements, relating to the needs and desires of potential users. Identification of the key criteria that determine the quality of potential intervention is the next phase in finding an alternative and sustainable solution to the problem of building obsolescence. According to the pre-defined housing criteria, the evaluation of the potential conversion project determines the cost-effectiveness and functionality of the proposed solution.

\subsection{General housing requirements}

Conversion of non-residential buildings to residential uses includes an analysis of the needs and wishes of potential tenants that match those in new residential community. In order to assess in which case the converted building can respond to the priorities and requirements of the tenants, it is necessary to define the key factors that have been decisive in the living environment selection. The offer should meet the specified requirements at all spatial levels, from the aspects of location and living environment to the aspects related to the building.

From the aspect of the location, comparison of the existing situation and demands is easier to implement than an analysis of the aspects related to the building. At the location level, it is necessary to analyse the facilities that are located in the vicinity, to determine location distance from public transport and give a general impression of the safety and quality of life in a particular environment. Evaluation of the suitability at the building level is quite complex. Some building characteristics can be considered as the conditions that facilitate or hinder the conversion process. These features do not have to be considered only in relation to the needs and requirements of potential tenants, but also to the technical possibilities of building conversion. In this regard, the extent to which existing structure meets requirements cannot be determined if the initial phase of the project does not include a detailed analysis of all aspects of conversion. 


\subsection{Evaluation criteria}

In order to implement a qualitative evaluation of abandoned building suitability for accepting the housing functions, it is necessary to define the key criteria that determine the quality of potential intervention as well as to define the profile of buildings that make a representative sample for research.

Conducted studies in the field of conversion define a wide range of individual criteria, viewed from the various housing aspects [8]. Five main groups of criteria for evaluating the suitability of conversions are architectural and structural, locational, financial, legal criteria and those that relate to the needs and requirements of potential users (Tab. 1) [9]. Based on defined criteria, opportunities and constraints of conversion implementation are assessed.

Table 1 Criteria for evaluating the quality of conversion [9]

\begin{tabular}{|c|c|}
\hline Physical / Design & Demand \\
\hline $\begin{array}{l}\text { - size/ height/ depth of } \\
\text { building } \\
\text { - space/ layout/ access/ } \\
\text { circulation } \\
\text { - building envelope/ cladding } \\
\text { - building structure } \\
\text { - building services }\end{array}$ & $\begin{array}{l}\text { - level of demand } \\
\text { - target market sector } \\
\text { - price structure } \\
\text { - aesthetic appearance } \\
\text { - interest rates } \\
\text { - car parking } \\
\text { - facilities }\end{array}$ \\
\hline Locational & \begin{tabular}{|c|} 
Legislative \\
\end{tabular} \\
\hline $\begin{array}{l}\text { - quality of the environment } \\
\text { - bad neighbour uses/ noises } \\
\text { - services and facilities } \\
\text { - convenience of car parking } \\
\text { - critical mass of housing } \\
\text { - safety and security } \\
\text { - views }\end{array}$ & \multirow{3}{*}{$\begin{array}{l}\text { - Planning policies } \\
\text { - affordable housing } \\
\text { - employment space } \\
\text { - privacy } \\
\text { - density } \\
\text { - amenity space } \\
\text { - parking } \\
\text { - Building regulations/ codes } \\
\text { - fire } \\
\text { - access } \\
\text { - heat loss/ acoustic } \\
\text { separation } \\
\text { - Environmental policies } \\
\text { - noise legislation }\end{array}$} \\
\hline Financial/Economic & \\
\hline $\begin{array}{l}\text { - attitudes of building owners } \\
\text { - tax (dis)incentives } \\
\text { - attitudes of investors } \\
\text { - availability of gap funding } \\
\text { - attitudes of developers }\end{array}$ & \\
\hline
\end{tabular}

In order to result with functional, aesthetic and costeffective solution, it is necessary to evaluate the quality of building conversion according to previously mentioned criteria. The rationality of conversion of abandoned buildings to residential buildings is therefore a complex issue and requires a detailed analysis of factors affecting the advantages and limitations of such strategic approach.

An important consideration in comparing and evaluating revitalization models is the type of neighbourhood being targeted. An important next step in gaining a richer understanding of the most promising initiatives will be to develop a more precise taxonomy of the types of neighbourhoods being served and the revitalization tools that have been found to be most effective for each neighbourhood type [10].

According to previous studies, potential users usually look for locations that are close to work and other multipurpose facilities, to which they are provided with quick and easy access [11]. For that reason, the greatest number of the conversion examples is placed in large cities throughout the United States, Canada and Western Europe. These cities are prominent economic, cultural and educational centres, characterized by high population density, multinational population and high living standard. In accordance with the modern lifestyle, for residential environment are therefore usually chosen the locations in frequent and dynamic urban areas. As the areas of demographic expansion are usually formed around the narrowest urban centres, because, as a rule, they are the most attractive areas of immigration, this location condition is used as initial data.

The four most common types of non-residential buildings that are the objects of conversion are industrial, warehouse, military and office buildings. Multi-criteria analysis and comparison of selected case studies within defined building groups identify the basic characteristics of typical conversion projects. Based on obtaining results, evaluation of suitability of the individual building type in order to accept the housing functions was performed.

Tab. 2 summarizes the main characteristics of the buildings that are the objects of conversion and the urban environment in which they are located. Within the study only those criteria related to architectural and structural characteristics of the building and the characteristics of the living environment were taken into consideration.

This research has an aim to define the common characteristics of conversion projects for defined typological structure and to determine the cases in which this transformation makes sense, seen from an architectural point of view.

\subsection{Results and discussion}

As already noted, the analysed conversion projects are located in the narrowest urban areas, rich with historical heritage and modern commercial, educational and cultural programs. By upgrading the residential environment in urban centres the structural and functional changes of the urban fabric were carried out, which is the basic principle of the current movement of urban regeneration. As these locations are characterized by high population density, the required parking area is usually planned in the basement and ground floor levels of the building or in one of the adjacent parcels, if locational conditions permit this. Common characteristics of all analysed examples are good connection to main roads and availability of public transport. All the examples of conversion are characterized by optimal visual and spatial qualities of location, which also proves to be an important parameter in selection of residential environment.

Despite the characteristic functions that they accept, most of the analysed buildings are suitable for this type of conversion, in structural and architectural terms. The process of conversion of abandoned buildings generally involves use of existing spatial structures or certain parts of a historic building, with a potential extension of the structure in order to expand the housing capacity and accommodate retail and business facilities. As these buildings are usually with long fronts, with a number of large openings in the facade and high storey height, the conversion process provides a high quality of living comfort. This implies optimal ventilation and insolation, good vision and connection with the natural environment.

Analysed typical structures are mostly composed of the frame structural system, where the expected stability 
of the building is achieved and the acceptance of additional load and capacity expansion is enabled. Most uniform structural modules, a wide range of bridging and "open plan" design within the existing structure, leave space for a quality solution of spatial configuration of building composition and allow the flexibility of individual housing units within the assembly. However, unlike the industrial, warehouse and military buildings, which are generally in the reduced and standardized form, constructive and architectural design of commercial buildings varies from case to case, and so it is difficult to overview the general conversion qualities.

Table 2 Conversion projects that are subjects of research

\begin{tabular}{|c|c|c|c|c|}
\hline No. & $\begin{array}{c}\text { Name and location of } \\
\text { the object }\end{array}$ & Location characteristics & $\begin{array}{l}\text { Type of existing } \\
\text { building }\end{array}$ & Characteristics of adapted building \\
\hline 1 & $\begin{array}{l}\text { Tip Top Tailor Lofts, } \\
\text { Toronto, Canada }\end{array}$ & $\begin{array}{l}\text { historical area near the city centre, along } \\
\text { the lake shore and the main road, with } \\
\text { business and commercial facilities }\end{array}$ & factory & $\begin{array}{l}\text { residential facilities within existing } \\
\text { structure and newly- designed } \\
\text { superstructure; }\end{array}$ \\
\hline 2 & $\begin{array}{c}\text { Folsom/Dore } \\
\text { Apartments, } \\
\text { San Francisco, USA }\end{array}$ & $\begin{array}{l}\text { area with residential, commercial and } \\
\text { industrial buildings with a wide network } \\
\text { of bus and subway lines }\end{array}$ & warehouse & $\begin{array}{l}\text { Residential facilities within existing } \\
\text { structure and newly- designed } \\
\text { superstructure; }\end{array}$ \\
\hline 3 & $\begin{array}{l}\text { Fort Point Lofts } \\
\text { Condominiums, } \\
\text { Boston, USA } \\
\end{array}$ & $\begin{array}{l}\text { zone rich with cultural and historical } \\
\text { heritage with major highways and a wide } \\
\text { network of public transport }\end{array}$ & warehouse & $\begin{array}{l}\text { residential and commercial facilities } \\
\text { within two historic structures and newly } \\
\text { designed superstructure }\end{array}$ \\
\hline 4 & $\begin{array}{l}\text { Fuller (Alta) Lofts, } \\
\text { Los Angeles, USA }\end{array}$ & $\begin{array}{l}\text { historical area near the city centre and } \\
\text { metro station, rich with the public } \\
\text { facilities }\end{array}$ & warehouse & $\begin{array}{l}\text { residential and commercial facilities } \\
\text { within existing object and newly- } \\
\text { designed superstructure; }\end{array}$ \\
\hline 5 & $\begin{array}{c}\text { Bogenallee apartments, } \\
\text { Hamburg, Germany }\end{array}$ & $\begin{array}{l}\text { residential area in the centre, rich with } \\
\text { public facilities and wide network of } \\
\text { public transport }\end{array}$ & office building & $\begin{array}{l}\text { residential facilities within existing } \\
\text { historic structure }\end{array}$ \\
\hline 6 & $\begin{array}{c}\text { Kales (Kreisge) } \\
\text { building, } \\
\text { Detroit, USA }\end{array}$ & $\begin{array}{l}\text { residential area in the centre, rich with } \\
\text { public facilities and wide network of } \\
\text { public transport }\end{array}$ & office building & $\begin{array}{l}\text { residential facilities within existing } \\
\text { historic structure }\end{array}$ \\
\hline 7 & $\begin{array}{l}225 \text { North Fourth } \\
\text { Lofts, } \\
\text { Columbus, USA }\end{array}$ & $\begin{array}{l}\text { central area of commercial and } \\
\text { residential buildings and advanced } \\
\text { network of public transport }\end{array}$ & office building & $\begin{array}{l}\text { residential and commercial facilities } \\
\text { within existing structure and newly- } \\
\text { designed annex }\end{array}$ \\
\hline 8 & $\begin{array}{l}\text { One Hanson Place, } \\
\text { Brooklyn, USA }\end{array}$ & $\begin{array}{l}\text { central zone of the city near main metro } \\
\text { and train stations, rich with commercial } \\
\text { and public facilities }\end{array}$ & bank & $\begin{array}{l}\text { residential and commercial facilities } \\
\text { within existing historic building }\end{array}$ \\
\hline 9 & $\begin{array}{l}\text { The Marquette } \\
\text { building, } \\
\text { St. Louis, USA }\end{array}$ & $\begin{array}{l}\text { central city area with business and } \\
\text { catering facilities and a wide network of } \\
\text { public transport }\end{array}$ & bank & $\begin{array}{l}\text { residential and commercial facilities } \\
\text { within existing historic structure }\end{array}$ \\
\hline 10 & $\begin{array}{l}\text { The Candy factory } \\
\text { lofts, } \\
\text { Toronto, Canada }\end{array}$ & $\begin{array}{l}\text { central city area with business and } \\
\text { residential buildings and a wide network } \\
\text { of public transport }\end{array}$ & factory & $\begin{array}{l}\text { residential and commercial facilities } \\
\text { within existing historic structure }\end{array}$ \\
\hline 11 & $\begin{array}{l}\text { Building 9, } \\
\text { Seattle, USA }\end{array}$ & $\begin{array}{l}\text { historical area near the city centre along } \\
\text { the lake shore rich with public facilities } \\
\text { and large park areas }\end{array}$ & navy barracks & $\begin{array}{l}\text { affordable housing within existing } \\
\text { historic structure }\end{array}$ \\
\hline 12 & $\begin{array}{l}\text { Le Marchant Barracks, } \\
\text { Devizes, England }\end{array}$ & $\begin{array}{l}\text { historical area near the city centre with } \\
\text { industrial, commercial and residential } \\
\text { facilitiesand advanced public transport }\end{array}$ & barracks & $\begin{array}{l}\text { residential facilities within existing } \\
\text { historic structure }\end{array}$ \\
\hline
\end{tabular}

Summing up the achieved results for specified building types, it is possible to make the systematization of works that are usually done within the process of conversion of typical non-residential buildings to housing facilities and determine the spatial context in which the intervention occurred.

The spatial relation between inherited building and newly designed unity is an influential factor in determining the degree of performed intervention. Figure 1 provides an overview of the possible spatial relations between historic building and newly designed structure in conversion process. Existing and newly designed structure can be spatially separated (A), connected (C) or intersected (I) of defined spatial legality [12].

Table 3 provides an overview of the results obtained by systematization of works made within individual case studies. Most of conversion projects involve combining of several methodological and technical procedures, while the extent of conducted work depends primarily on location, legislative, environmental and economic conditions.

In the examples of industrial and warehouse facilities, physical relation of intersection and connection (I \& C) is usually combined in the conversion process. The cause for this is often insufficient space capacity of the inherited typical structure. As such buildings are usually designed with flat roofs, easy upgrading of the building is enabled. For analysed examples of office and military buildings, physical capacities match the demanded housing conditions so the most common physical relation is intersection (I).

Category of spatial relation which involves the intersection of the units can occur in three physical forms: internal (I1), external (I2) and spatial relationship of partial permeation (I3). The conversion process identified in the case studies, in most cases, involves the implementation of interventions within the existing structures, where the outer layer of the building remains 
the same and the spatial organization is fully adapted to new functions (I1). Possible extensions planned by conversion projects are mainly located in the zone above the existing building (C3). Reason for this is a fact that densely populated urban centres are generally not able to accommodate additional contents in horizontal extensions, and there is no free space in the immediate vicinity of the inherited building.

From the above, it can be concluded that the adaptation and potential construction of the superstructure are the two most common types of intervention involved in the conversion process. Built superstructures are mainly characterized by form neutrality that does not compete with inherited historic structure. This phenomenon is a result of tendency of current sustainability movement and architectural heritage revitalization for integrative protection that establishes a compromise between culturally sustainable use of architecture and the contemporary needs of society. Contextualization of the built environment, with the accent on historical and cultural value of the inherited building, adapted to a new purpose only to the extent sufficient for its smooth functioning, is the basic definition of international conversion principle.

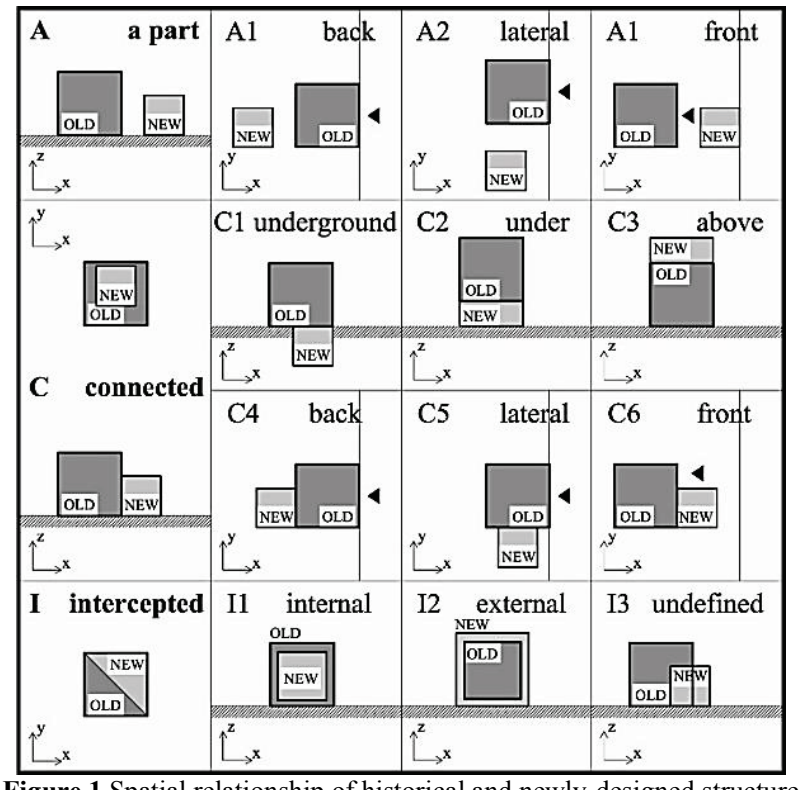

Table 3 Spatial relation between existing and newly-designed structure in individual case studies

\begin{tabular}{|c|c|c|c|c|c|c|c|c|c|c|}
\hline No. & Name of the building & Type of intervention & \multicolumn{8}{|c|}{ Spatial relation } \\
\hline 1 & Tip Top Tailor Lofts & adaptation and extension & $\mathrm{C} 1$ & $\mathrm{C} 3$ & & & & I1 & & \\
\hline 2 & Folsom/Dore Apartments & reconstruction and extension & & $\mathrm{C} 3$ & $\mathrm{C} 4$ & & & & & $\mathrm{I} 3$ \\
\hline 3 & Fort Point Lofts Condominiums & adaptation and extension & & $\mathrm{C} 3$ & & $\mathrm{C} 5$ & & I1 & & \\
\hline 4 & Fuller (Alta) Lofts & adaptation and extension & & $\mathrm{C} 3$ & & & & I1 & & \\
\hline 5 & Bogenallee apartments & reconstruction and extension & & & & & C6 & & $\mathrm{I} 2$ & \\
\hline 6 & Kales (Kreisge) building & adaptation & & & & & & I1 & & \\
\hline 7 & 225 North Fourth Lofts & adaptation and extension & & & & $\mathrm{C} 5$ & & I1 & & \\
\hline 8 & One Hanson Place & adaptation & & & & & & I1 & & \\
\hline 9 & The Marquette building & adaptation & & & & & & I1 & & \\
\hline 10 & Candy factory lofts & adaptation & & & & & & I1 & & \\
\hline 11 & Building 9 & adaptation & & & & & & I1 & & \\
\hline 12 & Le Marchant Barracks & adaptation & & & & & & I1 & & \\
\hline
\end{tabular}

\section{$5 \quad$ Building obsolescence and current housing policy in the Republic of Serbia}

In order to perceive the actual housing policy which is implemented on the territory of Serbia, seen from the aspect of conversion, the representative examples of abandoned facilities treatment were taken into consideration. With appropriate urbanistic and architectural approach, the conversion projects of several industrial, commercial, and military buildings to residential uses are planned on several specific locations. The final objective of this specific research is to determine the extent to which the strategic principles of conversion correspond to those identified on an international level.

\subsection{The subjects of analysis}

In accordance with the current global trend of industrial and military zones relocation from the city centre, old and abandoned factory and military facilities are replaced with business, residential and commercial complexes and moved to the peripheries of the cities. Conversion projects at eight analysed locations, which are partly constructed and partly in phase of realization, are presented to the public as the representative examples of successful urban regeneration and revitalization of the central city area.

In the nineties, a large number of industrial and commercial buildings faced with the problem of obsolescence and, in a short time, the world-renowned industrial giants stopped working. Sales of former socialist industrial giants through tenders or through bankruptcy have become an established way of privatization of urban construction land. The all-out land privatization, loss or progressive threat of public spaces and buildings of architectural heritage for the sake of private gain, insisting on a partnership of the private and public sector in civil engineering, have become the fundamental features of contemporary urban transformation of Serbia.

Tab. 4 provides an overview of abandoned buildings and locations that are subjects of analysis and general construction work planned within the conversion process. Buildings are positioned in the central city zones in which the formation of a compact urban environment with highly mixed facilities and advanced system of public transport are the main strategic goal of sustainability. 
Table 4 Representative projects of conversion on the territory of Serbia

\begin{tabular}{|c|c|c|c|c|}
\hline No. & Name and location of the object & $\begin{array}{l}\text { Type of existing } \\
\text { building }\end{array}$ & $\begin{array}{c}\text { Type of newly-designed } \\
\text { facilities } \\
\end{array}$ & Type of intervention \\
\hline 1 & $\begin{array}{c}\text { "INEX-Partizanka", } \\
\text { Ćirila i Metodija Str., Belgrade }\end{array}$ & Factory & Residential complex & $\begin{array}{l}\text { Partial reconstruction of existing building } \\
\text { and construction of new facilities }\end{array}$ \\
\hline 2 & $\begin{array}{c}\text { "BIP", Belgrade, } \\
\text { Skadarlija, Belgrade }\end{array}$ & Factory & $\begin{array}{l}\text { Retail, office and hotel } \\
\text { facilities }\end{array}$ & $\begin{array}{c}\text { Demolition of existing buildings and } \\
\text { construction of new facilities }\end{array}$ \\
\hline 3 & $\begin{array}{c}\text { „IKL“, Belgrade, } \\
\text { Knez Danilova Str., Belgrade }\end{array}$ & Factory & $\begin{array}{l}\text { Residential and commercial } \\
\text { complex }\end{array}$ & $\begin{array}{l}\text { Demolition of existing buildings and } \\
\text { construction of new facilities }\end{array}$ \\
\hline 4 & $\begin{array}{c}\text { "Beko", } \\
\text { Dorćol, Belgrade }\end{array}$ & Factory & $\begin{array}{c}\text { Residential and hotel } \\
\text { complex }\end{array}$ & $\begin{array}{l}\text { Demolition of existing buildings and } \\
\text { construction of new facilities }\end{array}$ \\
\hline 5 & $\begin{array}{c}\text { "4. Juli", } \\
\text { Voždovac, Belgrade }\end{array}$ & Military building & $\begin{array}{l}\text { Residential, educational } \\
\text { and commercial facilities }\end{array}$ & $\begin{array}{l}\text { Demolition of existing buildings and } \\
\text { construction of new facilities }\end{array}$ \\
\hline 6 & $\begin{array}{c}\text { "IMT", } \\
\text { Rakovica, Belgrade }\end{array}$ & Factory & $\begin{array}{c}\text { Residential and commercial } \\
\text { complex }\end{array}$ & $\begin{array}{c}\text { Demolition of existing buildings and } \\
\text { construction of new facilities }\end{array}$ \\
\hline 7 & $\begin{array}{c}\text { "Bubanjski heroji", } \\
\text { Palilula, Niš }\end{array}$ & Military building & $\begin{array}{l}\text { Residential and commercial } \\
\text { complex }\end{array}$ & $\begin{array}{l}\text { Demolition of existing buildings and } \\
\text { construction of new facilities }\end{array}$ \\
\hline 8 & $\begin{array}{c}\text { "Napredak", } \\
\text { Strahinjića Bana Str., Leskovac }\end{array}$ & Factory & Residential complex & $\begin{array}{l}\text { Partial reconstruction of existing building } \\
\text { and construction of new facilities }\end{array}$ \\
\hline
\end{tabular}

On the foundations of the former socks factory "InexPartizanka", located in a wide centre of Belgrade, the residential complex "Oasis" was developed in 2005. "Oasis" is a luxurious residential and commercial condominium, with an inner courtyard designed as a park area and a two-storey underground parking garage. The construction was accompanied by the frequent protests of former workers of "Partizanka" who believed that their factory was sold cheaply and tried to prevent its demolition. The intervention included partial reconstruction of existing building and construction of some additional facilities (Fig. 2).

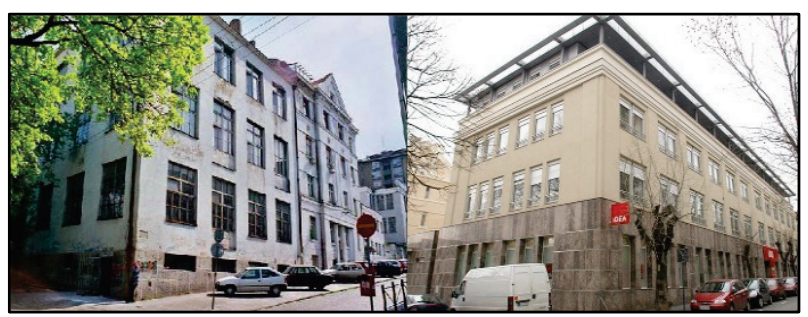

Figure 2 The old factory "Partizanka" before and after conversion

After a series of failed attempts to sell the beer factory complex in Skadarlija, which was particularly controversial because it was the nationalized assets of industrialist Bajloni, the land of 1,5 hectares and 14000 square meters of buildings was sold in 2006 to the company "Star Immobilijare". The former site of the Belgrade-based beer producer, "BIP" will be converted to a residential complex, including the mixed-use retail, office and hotel space. The site is very attractive due to its prime location in the centre of Belgrade, where it is adjacent to the Bohemian quarter of Skadarlija. Planned intervention includes complete demolition of existing buildings and construction of newly designed facilities (Fig. 3).

In November 2006, during the machinery relocation to the new site in Barajevo, the plant of "IKL" industry in the Knez Danilova Street in Belgrade burned down. The plot was soon sold to the private investors who plan to build the major residential and commercial complex. According to the project, about 500 residential units and retail space on the ground floor will be constructed within the complex. The buildings will be energy efficient with an abundance of greenery and a private park in the middle of the complex. Due to a number of irregularities during the process of privatization and sale of the factory, the criminal proceedings were initiated. Planned intervention includes complete demolition of existing buildings and construction of newly designed facilities (Fig. 4).

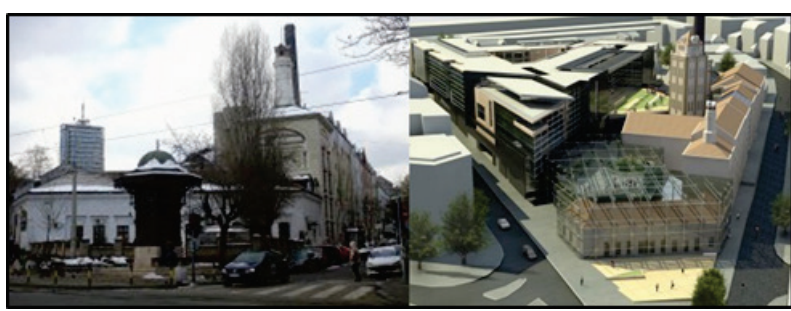

Figure 3 Former beer factory "BIP" and newly designed complex

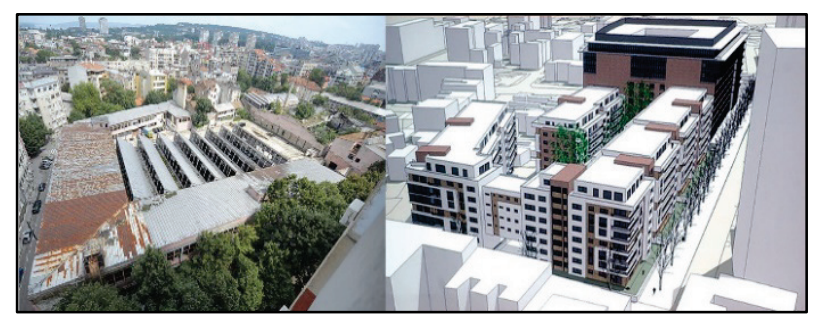

Figure 4 The old factory "IKL" and newly designed complex

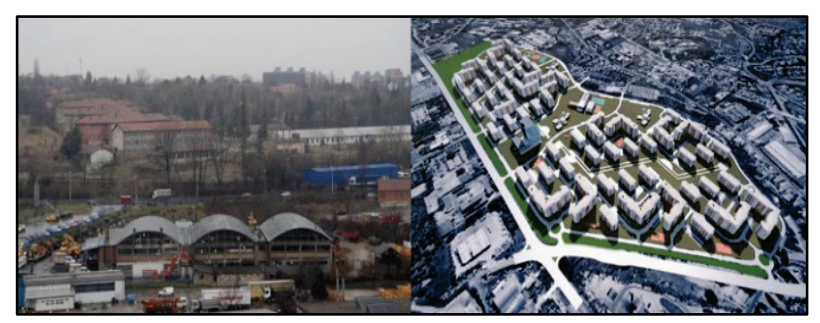

Figure 5 The old military complex " 4 . Juli" and newly constructed complex "Stepa Stepanović"

The old textile factory of Belgrade (Beko) in the city center of Dorćol (Duke Bojovića Street) was sold in 2007 to the Greek company "Lamda Development". Considering several solutions of invited leading global architectural bureau, "Lamda Development" finally chose the proposal by "Zaha Hadid Architects". "Zaha Hadid 
Architects" has designed a swirling complex of apartments, offices and leisure facilities on the abandoned site of the factory. The proposed cluster of buildings will accommodate a five-star hotel, a congress centre, galleries and shops, as well as the underground parking facilities for visitors and residents. The intervention includes complete demolition of existing buildings and construction of newly designed facilities (Fig. 5).

Military complex "Stepa Stepanović" in Voždovac, Belgrade is one of the locations with newly designed modern resort for thousands of people built in 2010, as a part of a social housing strategy. The complex area of 42 acres accommodates 44 buildings of residential, commercial and public facilities, defined in accordance with the needs of about 13000 inhabitants. Beside the residential buildings, the complex provides two primary schools, two preschools and kindergartens, office and commercial buildings, health centre, large parking space and green market. The conducted interventions included complete demolition of existing buildings and construction of newly designed facilities (Fig. 6).

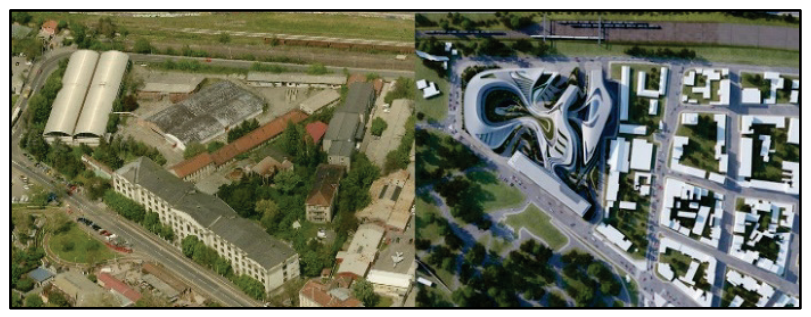

Figure 6 The old textile factory "Beko" and newly designed complex

In 2011, The US Company "Clean Earth Capital" bought the land of the former military building "Bubanjski heroji" in the centre of the City of Niš. An area of more than 15 acres will accommodate a hotel, shopping mall, foreign university and residential buildings that will occupy about $50 \%$ of the entire surface. Newly designed "Novi Niš" will represent a modern commercial and business centre placed in the Municipality of Palilula. The investor has taken the commitment to remove all current facilities and transferred the living space of 21000 square meters for the needs of the Army of Serbia, in accordance with the agreement on the exchange of property between the city and the Ministry of Defence. The construction of the complex will last between 8 and 10 years. The project planned intervention includes complete demolition of existing buildings and construction of new facilities (Fig. 7).

Development of social non-profit housing on the territory of the capital, could also be implemented at the lots of the former factory IMR (Municipality of New Belgrade) and IMT (Municipality of Rakovica). City of Belgrade carried out the conversion of the land from industrial to residential and commercial by which 77 new acres are available and suitable for the development of cheaper squares.

From 2008, once the most powerful printing office in the South Serbia "Napredak", located in the City of Leskovac, was in bankruptcy. In the same year, the initiative for its conversion from industrial to residential complex has been launched. Complex located in the central city area, rich with a variety of residential, cultural and commercial amenities corresponds to the quality standards set for housing in urban areas. The intervention includes partial reconstruction of an existing building and construction of new facilities. Conversion and extension project is currently underway (Fig. 8).

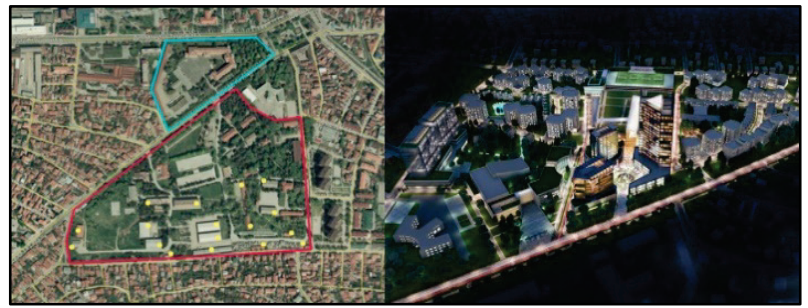

Figure 7 Former barracks "Bubanjski heroji" and newly designed "Novi Niš"

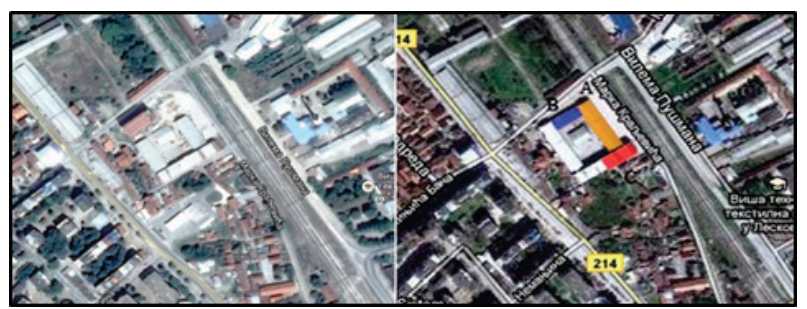

Figure 8 The old printing office "Napredak" and newly designed complex

\subsection{Results and discussion}

Many factories and companies, which were in the bankruptcy proceedings due to debts, were sold to private individuals at low cost, while the detailed regulation plan converted the industrial or commercial zone to urban construction land. Contemporary and original urban and architectural design of multifunctional complexes, backed by renowned names of the world of architecture, certainly improve the quality of life in such environment and make it attractive and appealing to both tourists and potential tenants. However, only few of these ambitious projects have taken into consideration the possibility of utilization the existing building resources found on the site. Seen from the point of sustainability and architectural preservation, this can be considered as a negative phenomenon. Interventions conducted within the land conversion process usually involve the building demolition, land "sterilization" and construction of new facilities of appropriate functions.

The reason for this is the lack of appropriate legislation that would constitute legal support and channelling development programs and projects that would, among other things, advocate the preservation and revitalization of the existing building fund. Experts in the field of architectural heritage are helpless against the current policy of alienation of the state construction property because there is no appropriate legal framework for the control of future activities of owners and investors. Building demolition and land clearing should be the last option of urban regeneration, applied only if conducted analysis proved it to be the only viable solution.

Urban policy restructuring should be achieved by the current principles of the "new urbanism", which as part of its strategy includes the issue of protection of historical heritage and sustainable development of "brownfield" 
sites. A new model of urban regeneration has to be formed on the positive experience of the developed countries of Europe and the U.S., as well as a small number of viable conversion projects implemented with the support of the government and international institutions in Serbia.

\section{Conclusions}

With a suitable flexible and positive planning policy, structures of the existing building fund, which are out of their primary function, may be transformed into buildings of different purposes. The potential for converting abandoned buildings into housing facilities results from the relation between the offer within an existing outdated building fund and the increasing demand for new housing environment.

At international level, conversion projects which are largely located in the tightest city areas, mostly include the renovation or reconstruction of the existing buildings with possible extensions, if locational conditions permit this. The level of achieved intervention and the relationship of the existing and newly designed structure mainly depend on the physical capacity of the building, existing location, legislative conditions as well as the imposed requirements of sustainability.

Opportunities for conversion, both depend on the factors related to functional and aesthetic characteristics of the building and many external factors such as market conditions, planning policies and motives of individual owners and investors. Therefore, the creation of a strategic policy framework and action planning and construction are considered as a necessity since they would enable, in a sustainable manner and with comprehensive support of the government and local communities, utilization of the existing building potentials, according to particular internal and external conditions. Sustainability of the approach will depend on the extent to which the negative characteristics and constraints can be overcome as well as the extent to which the positive features and potential can be utilized.

Seen from the point of sustainability, the local trends of land conversion followed by complete demolition of the existing facilities, without considering their reuse through conversion process, can be seen as a negative phenomenon. Following the positive experience of developed international cities, it is necessary to make a serious analysis of the possibilities of obsolete building reuse before the radical measures of their demolition and new building development would be taken.

\section{Acknowledgements}

The paper was done within the project "Optimisation of architectural and urban planning and design in function of sustainable development in Serbia", no. TR 36042, funded by Ministry of Education and Science, Republic of Serbia.

\section{References}

[1] Kurtovic-Folic, N. Conservation through conversion. // Proceedings of the $11^{\text {th }}$ International Scientific Conference VSU' 2010, Vol. II / Sofia, 2011, pp. 64-72.

[2] Yildirim, M. Assessment of the decision-making process for re-use of a historical asset: The example of Diyarbakir Hasan Pasha Khan, Turkey. // Journal of cultural heritage, 13, (2012), pp. 379-388.DOI: 10.1016/j.culher.2012.01.018

[3] Bullen, P. A.; Love, P. E. D. The rhetoric of adaptive reuse of reality of demolition: Views from the field. // Cities, 27, (2010), pp. 215-224.DOI: 10.1016/j.cities.2009.12.005

[4] Heath, T. Achieving Sustainable Urban Form through Adaptive Re-use of Buildings for Residential Use // Achieving Sustainable urban form. E\&FN Spon, London, 2000.

[5] Snyder, G. H. Sustainability through adaptive reuse. // A thesis submitted to the Division of research and advanced studies of the University of Cincinnati, Cincinnati, 2005.

[6] Clark, K. Planning for the past: heritage services in local planning authorities in England. // Cultural trends, 11, 43/44(2001), pp. 61-96.DOI: 10.1080/09548960109365166

[7] English heritage. // Sustaining the historic environment: new perspectives on the future. English heritage, London, 1997.

[8] Tanaç, Z.M. Adaptive re-use of monuments "restoring religious buildings with different uses". // Journal of cultural heritage, 14, 3(2013), pp. S14-S19. URL:http://www.sciencedirect.com.proxy.kobson.nb.rs:204 8/science/article/pii/S1296207413000356 (5.3.2014.)

[9] Geraedts, P. R.; Voordt, T. Offices for living in. // Proceedings of CIB Conference Open House Implementation / Mexico City, 2002, pp. 4-12.

[10] Johnson C. Review of Neighborhood. Revitalization Initiatives. Neighborhood Reinvestment Corporation, Boston, 2004.

[11] Heath, T. Adaptive re-use of offices for residential use. // Cities 18, (2001), pp. 173-184.DOI: 10.1016/S02642751(01)00009-9

[12] Pereira, R.; Post, J.M.; Erkelens, P.A. Reusing built heritage resources with sustainability. // Sustainability and Innovation in Construction and Real Estate, Proceedings of the 2nd CIB Student Chapters International Symposium, Tsinghua University / Beijing, China, 2004, pp. 727-736.

\section{Authors' addresses}

Milica Živković, Assistant, MSc

Goran Jovanović, Associate Professor PhD

Slaviša Kondić, Assistant, MSc

Mihailo Mitković, Assistant, MSc

Faculty of Civil Engineering and Architecture

Aleksandra Medvedeva 14

18000 Niš, Serbia

E-mail: dia.milica@gmail.com

E-mail: goran.jovanovic@gaf.ni.ac.rs

E-mail: skondic555@yahoo.com

E-mail: mihailo.mitkovic@gaf.ni.ac.rs

Nađa Kurtović-Folić, Full Professor PhD

Faculty of Technical Sciences

Trg Dositeja Obradovića 6

21000 Novi Sad, Serbia

E-mail: nfolic@gmail.com 